\title{
Environmental Management Practices on Financial Performance: With Special Reference to the Rubber Industry in Sri Lanka
}

\author{
D. Gunathilaka
}

University of Sri Jayewardenepura

\section{K.D. Gunawardana}

University of Sri Jayewardenepura

\begin{abstract}
This study investigates the relationship between environmental management practices $(E M P S)$ on financial performance $(F P)$ using the data from thirty rubber manufacturing organizations by building panel models for the sample during the period of 2012-2016. The study has considered the three different EMPs of energy reduction (amount of furnace oil use per day), waste (amount of waste water generates), and recycle (amount of recycle raw material) in capturing the effect of EMPs on FP. In addition, to elucidate how financial performance is dealing with EMPs, the study used Return on Assets (ROA) as a determinant of financial performance. It is more difficult to identify the general relationship between EMPs and FP of firms due to its heterogeneity during the growth of firms.' The estimation results suggested that the recycling of waste material had significant negative driving forces on FP. However, waste water treatment and furnace oil consumption had no significant impact on FP. Therefore, it is critical to investigate the relationship between FP and EMPs which is yet to be resolved in order to build up a scope for companies to implement better environmental practices in the organizations.
\end{abstract}

\section{Keywords}

Environmental management practices; financial performance; rubber industry 


\section{Introduction}

Today's organizations are experiencing a very high level of pressure due to travails of competition generated from globalization, technological changes and many other forces in the environment. Agan, Acar and Borodin (2013) stressed that climate change and environmental pollution are universal challenges for the society, and it will remain as hot topic of discussion at global level. Montabon, Sroufe and Narasimhan (2007) stressed that the contradiction between EMPs and FP has been a great interest in the research literature. Rondinelli and Vastag (1996, p. 998) claimed that, firms are reacting to an "increasingly difficult regulatory environment or responding to market pressure in adapting EMPs and the responses of firms to exogenous pressures have led to EMPs that impact profitability". Montabon, Sroufe and Narasimhan (2007) elaborated on efficient utilization of resources that may improve the corporate image through proactive environmental approach or anticipatory activities. A growing debate on how EMPs affect the FP of an organization is still contradictory. To some extent, results are isolated and conflicting to confirm whether the findings are positive, negative, mixed or no results. Klassen and Whybark (1999) discussed environmental performance as a matter of output in environmental management, which refers to the firm's activities and products on the natural environment. Burritt (2004) stressed that adopting environmental protection measures can reduce costs. Further, Schaltegger and Wagner (2006) noted that eco efficiency improves the relationship between economic performance and environmental impacts. Lawrence and Morell (1995) discussed the motivations in adapting environmental practices and found that environmentally proactive organizations motivated by regulations, cost reductions and not being targeted by environmental pressure groups. Delmas (2003) studied on plant- and parent company-specific factors, including their track record of environmental performance, the competitive position of the parent company and the organizational structure of the plant and found the importance of adapting environmental management practices to respond these institutional and stakeholder pressure by accepting different environmental management practices. It shows that key question is still open for researchers to identify the 
relationship between EMPs and FP under the present circumstances. Thus, the current study aims to investigate such relationship.

Rubber being a very essential agricultural commodity in the Sri Lankan economy, climate risk is one of the major risk components that have got adversely fastened to businesses in the rubber industry. Physical changes in climate are expected risk in macro-circumstances which lead to extreme whether events and gradual modification of climate, which would affect the change equilibrium of businesses and already weather manifests itself in sensitive rubber manufacturing processes. Manufacturing has a role to play in both climate change mitigation and adaptation. On the other hand, rubber processing is categorised as one of the major polluting industries according to the published records by Central Environmental Authority (CEA) of Sri Lanka (Edirisinghe, 2013). Edirisinghe (2013) further stated that 40-50 litres of effluent are discharged on the average of one kilogram of rubber production. Thus, environment management practices are essential in this industry. Therefore, current study considers it as the study context.

\section{Literature Review}

\section{Environment Management Practices}

Colby (1991) stressed that the environmental concern as almost absent in the economic debates in the early 1970s and focused on the competitive markets and the dominant theoretical approach which was Frontier Economics paradigm. Further, they provided more attention on reactive and cost mode which was characterized through environmental protection and deep ecology, and in this stage the main concern was compliance and regulations. The next stage is proactive and sustainable business mode which is going beyond the compliance and found as the way to resolve damage caused by industrial activity and the domain theoretical approach was resource management paradigm (see Figure 1). The last stage was eco-development paradigm which was managed to reveal the resource management's solutions which are not enough to find the solution through more environmentally sound measures. 
Figure 1: Berry and Rondinelli (1998) and Colby (1991) classification on compliance

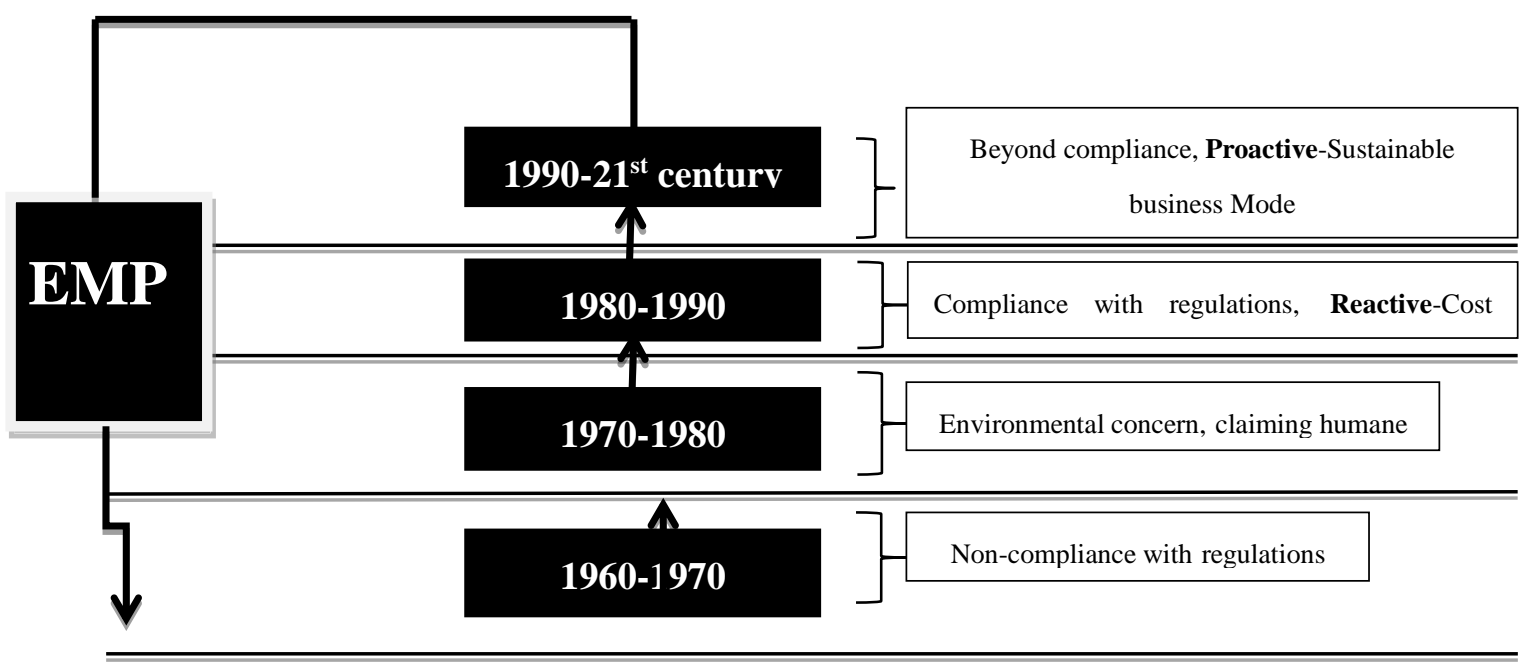

Source: Author's own elaboration

González-Benito and González-Benito (2005) constructed a comprehensive review of environmental analysis based on environmental management practices into three categories. Accordingly, there were three-fold of environmental management practices in operations, such as operation functions related practices, planning and organizational practices and communicational practices. Operational practices are related to operations and the production systems, which classified as two categories: product-related practices and process related practices. The extent to which the company has defined an environmental policy was denoted by the Planning and Organizational Practices and communicational practices aimed at communicating of actions favour to the natural environment.

\section{- Working definition for EMPs:}

"EMPs are the techniques, policies and procedures a firm uses that are specifically aimed at monitoring and controlling the impacts of its operations on the natural environment" (Montabon, Sroufe and Narasimhan, 2007, p. 998).

Measurement of EMPs: furnace oil consumption in liters, waste treatment in 
cubic meters and recycles of raw material in kilogram.

\section{- Working Definition for Waste Treatment:}

"Stabilisation, preferably by accelerated degradation, so that the final residues produced are either non-toxic and incapable of further change, that is they are completely mineralized, or able to find ready entry into the various natural bio-geochemical (elemental) cycles that groven materials cycling in the environment, without causing distortion in any cycle relative to another" (Hamer, 2003 as cited in Agan, Acar and Borodin, 2013 p. 24).

\section{- Working Definition for Reduction: (finance oil consumption)}

"Focusing on preventing pollution at the source (in products as well as manufacturing process) rather than managing it" (Srivastava, 2007 as cited in Agan, Acar and Borodin, 2013 p. 24).

\section{- Working Definition: Internal Recycling:}

"The reuse of materials from returned products without conserving the product identity" (Kapetanopoulou \& Tagaras, 2011, as cited in Agan, Acar \& Borodin 2013, p. 24).

\section{Financial Performance (ROA)}

Operating Performance is the performance of a company based on the profit recorded in the financial statements. It is measured by return on equity (ROE) and return on assets (ROA). ROE and ROA indicate how efficient the company generates profits or earnings based on shareholders' equity and company's total assets respectively. Market Valuation is the performance of the company based on its market value in the capital market, The Market valuation of the firm is commonly measured by Tobin's Q and market-to-book (MTB) ratio. For instance, Tobin's Q is popular amongst researchers such as Bhagat and Bolton (2008). This ratio measures company's assets in relation to the market value. A ratio less than 1 indicates it costs more to replace firm assets as compared to how much it is worth. In this research ROA is the measure of the financial performance. 


\section{Theory Base}

Institutional theory emphasis on the legitimation process and tendency for institutionalized organizational structures and procedures to be taken for granted, regardless of their efficiency implications (Hoffman and Ventresca, 2002). DiMaggio and Powell (1983) argued that managerial decisions are strongly influenced by three institutional mechanisms coercive, mimetic, and normative isomorphism that create and diffuse a common set of values, norms, and rules to produce similar practices and structures across organizations that share a common organizational field. Jennings and Zandbergen (1995) were amongst the first to apply institutional theory to explain firms' adoption of environmental management practices. They argue that coercive forces, primarily in the form of regulations and regulatory enforcement are the main impetus of environmental management practices, and firms throughout each industry have implemented similar practices (Jennings and Zandbergen, 1995). Further, Amores-Salvadó et al. (2012) emphasized that Natural Resource-Based View (NRBV) to achieve ecologically and socially sound solution without renouncing the financial implication of the organization.

Bierbaum (2008) explained in her Polycentric approach for coping with climate change research paper that "Adaptation to climate change is lagging which mean that not making progress in understanding vulnerability to climate change and its potential impacts on humans, conducting risk analysis, or understanding what stakeholders want from science to aid decision making" (p. 2 as cited in Ostrom 2015). The conventional theory of collective action is required as a support from a behavioural theory of human action, affecting the level of thrust and reciprocity of those who are involved into analysis of individual involvement in natural resource at different levels (Ostrom, 2009). With such broader perspective, the current study considers the Resource Based View as the main theory.

\section{Environmental Impact from the Rubber Industry}

Rubber sector organizations are susceptible to weather sensitivity in the raw material stage. The carbon intensity risk is associated with the modification of 
the equilibrium of business, caused by reduction of raw rubber harvest and the price fluctuation of commodities in the market (Figure 2). The changes in weather patterns lately have had detrimental effect on rubber output such as uncertainty of supply and demand, black market price, price fluctuations due to surpluses and radical price variation in the process of raw material intake and risk in stocks. Excessive rain diminishes the tapping sequence, resulting in a short supply situation of latex causing an increase in rubber prices locally and also it compels manufacturers to resort to ad-hoc import of natural rubber. Generally, the export prices are decided well in advance and such deviations in raw material prices will result in loss of profits or even losses.

Figure 2: World rubber prices - 2010 November to 2016 August (yen)

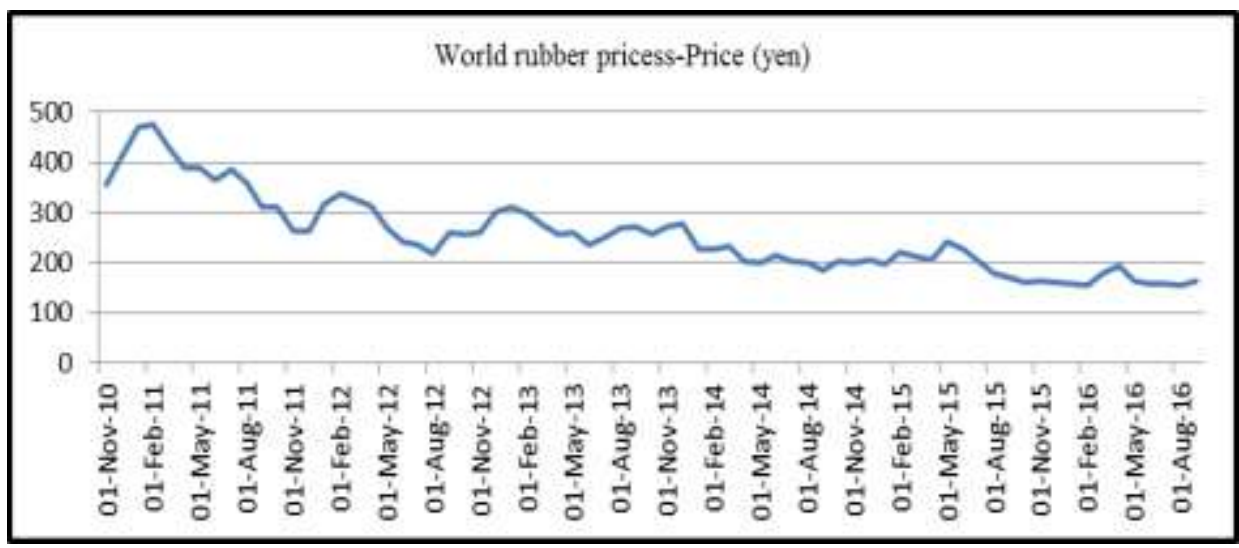

Source: Author's own elaboration (prices adapted from TOCOM rubber market)

Rubber manufacturing process is heavily depending on heating which is the main cause of climate change due to emissions. The insufficient hydroelectric power and low rainfall in relevance to weather changes what we are experiencing in the meantime will drive industries into the use of burning furnace oil. Burning fossil fuel is a governing factor in increasing emissions. Environmental pollution through the use of water in the industry is yet another major concern. Environmental authorities have given organizations very strict compliances to follow and are much more vigilant as this issue has caused much uproar in the recent past in the society. Gunathilaka and Gunawardana (2015); 
Gunathilaka, Gunawardana, and Pushpakumari (2015) found that the emission of $\mathrm{CO} 2$ is doubled in conventional rubber product compared to that of organic product while operating other process parameters under same conditions. The other danger associated with rubber cultivation highlighted by Houghton and Hackler (1999) attributing the reason of deforestation and burning of natural forest to convert land to rubber has reduced carbon stocks above- and below-ground by increasing the rate of carbon emissions.

According to Edirisinghe (2013) total production of 114, 700 metric tonnes of rubber in 2006 produced and discharged 4.5 to 5.7 billion litres of effluent to the environment. There are three main grades of natural rubber produced (Table 1) such as ribbed smoked sheets (RSS), crepe rubber and centrifuge latex, effluent generate by such production processes contains 30-40 per cent of rubber and 60-70 per cent serum substances (Edirisinghe, 2013).

Table 1: Types of Energy use in Rubber Product Manufacturing

\begin{tabular}{lll}
\hline Industry Division & $\begin{array}{l}\text { Rubber Products (more than } \\
\text { 25 persons engaged factory) }\end{array}$ & $\begin{array}{l}\text { Rubber \& Plastic (less } \\
\text { than 25 persons engaged } \\
\text { factory) }\end{array}$ \\
\hline Fuel \& Electricity Total & $4,813,983,284$ & $353,138,433$ \\
(Rs.) & & \\
Electricity (Rs.) & $2,614,359,207$ & $260,424,778$ \\
Furnace (Rs.) & $896,085,259$ & $15,619,075$ \\
Diesel (Rs.) & $314,977,700$ & $24,944,532$ \\
Kerosene (Rs.) & $52,972,080$ & 737,867 \\
Petrol (Rs.) & $47,850,814$ & $4,534,100$ \\
L.P.G. (Rs.) & $20,530,227$ & $37,888,271$ \\
Charcoal (Rs.) & $208,096,259$ & 14,600 \\
Firewood (Rs.) & $452,702,089$ & $3,661,274$ \\
Water (Rs.) & $190,168,153$ & $3,536,752$ \\
Other fuel (Rs.) & $16,241,497$ & $1,777,183$ \\
\hline
\end{tabular}


Rubber serum substances contain amino acids, carbohydrates and lactic acid with substances required for plant growth and some chemicals such as sodium sulphite, ammonia or formalin, formic acid, acetic acid, oxalic acid, sodium bisulphite, metabisulphite and xylyl mercaptan which are added in the processing of centrifuging. The most adverse effect could be created due to influents is pollution of groundwater and effluents cannot be used for other purposes (Kudaligama et al. 2004 as cited in Edirisinghe, 2013). Heavy usage of energy has been depicted in the above sub-sections (see Table 1), is another contrasting factor. Another concerning point is solid and liquid waste generated from manufacturing operations. Thus, it is worthwhile investigating into the real reasons for environmental transition from both the environmental management and the environmental performance in the rubber industry.

On the other hand, one of the main targets of corrective action for climate change is to grow more rubber However, growing rubber trees is now categorized under secondary "forest cover" would certainly have better financial implications to the industry. According to Central bank (2014) reports that declined growth of rubber cultivation in last few years, as recorded in total extent in 134000 hectares in 2014 and 135000 hectares in 2015, shown slight inclination 2014 to 2015, 0.7\% growth compared 2013 to 2014. Growing of more rubber trees is considered a feasible solution that helps to reduce climate risks whilst helping to reduce atmospheric carbon. This can be viewed as leaving a good financial implication as more rubber means better prices and also less interruption to manufacturing.

\section{Hypotheses Development}

DiMaggio and Powell (1991) argued that managerial decisions are strongly influenced by three institutional mechanisms, coercive, mimetic and normative isomorphism that create and diffuse a common set of values, norms, and rules to produce similar practices and structures across organizations that share a common organizational field. Proliferation of the 'best of' rankings has created incentives to rank high to enhance corporate reputation. Meyer and Rowan (1977) 
defined isomorphism as "organizations are driven to incorporate the practices and procedures defined by prevailing rationalized concepts of organizational work and institutionalized organizations that do so increase their legitimacy and their survival prospects, independent of the immediate efficacy of the acquired practices and procedures". The inclination towards homogeneity is called 'isomorphism (Powell, 1991). The term Mimetic represents the pressures arising from the perspective to reduce uncertainty (Davidsson et al., 2006). These pressures show the mechanism by which the cultural pillar influences its power (Mignerat and Rivard, 2005). Levy and Rothenberg (2002) described several mechanisms by which institutionalism can encourage heterogeneity. First, they argued that institutional forces are transformed as they permeate organizational boundaries because they are filtered and interpreted by managers according to firms' organizational unique history and culture. For example, 'a firm's history with environmental technology influenced the degree to which future technological options were viewed as an opportunity or a threat' (Levy and Rothenberg, 2002; Gunathilaka and Gunawardana, 2018). Second, they described how an institutional field may contain conflicting institutional pressures that require prioritization by managers. Third, they described how multinational and diversified organizations operate within several institutional fields both at the societal and organizational levels which expose them to different sets of institutionalized practices and norms.

Environmental management (EM) affects both the structural and the infrastructural components; that means the product and the process technology and underlying management systems. Operations strategy is defined environmental management as a 'pattern of structural (plant and equipment) and infrastructural choices (production planning, performance measurement, and product design) that guide decisions in the operations to support overall firm objectives' (Hayes and Wheelwright, 1984). Further, they described that product technology involving the use of recycled raw materials or post-consumer recycling and process technology incorporate more efficient production systems, 'end-of- pipe' control technology and preventative barriers. Further, Environmental Management System (EMS) comprehends worker training and 
environmental audits and process discharge. Jorgensen (2000) defined Environmental Management System as a mode of providing a systematic approach to manage the environment, if giving at the top priority it reflects the company vision, mission, policy, strategies, and actions (Cited by Aggarwal, 2013). In 1992, the first EMS standard was applied in the UK. In 1996, the first EMS standard on the international scale, known as the ISO 14001 was introduced and further reviewed it in 2004 (Sakr et al., 2010 cited by Aggarwal, 2013). This certificate mandated five requirements such as Environmental policy, Planning, Implementation, Checking, and Management review (ISO, 2004). Aggarwal mentioned that environmental management is a holistic approach resolving the environmental issues that companies face. Aggarwal, (2013, p. 25) defined it as "Operating in a socially responsible, sustainable, and profitable way" Furthermore, Jorgensen (2000) defines Environmental Management System as "Providing a systematic approach to manage the environmental protection of the company" (as cited Aggarwal, 2013, p.25).

Sharma and Vredenburg (1998) and Correa et al. (2008) discussed that small medium enterprises perform both proactive as well as reactive environmental management practices towards eliminating environmental pollutants or waste (as cited Aggarwal, 2013). Further, they mentioned in the same paper that such activities from waste treatment to developing sophisticated environmental management practices. Aggarwal (2013) clarified that in the past literature, these activities were labeled as actions, performance, behaviors, applications, practices or system. The practices discussed in this paper are waste treatment, recycling, and energy consumption (furnace oil reduction). In environmental practices reduction is referred to as conservation of energy, water, and raw materials (Aggarwal, 2013). Aggarwal (2013) mentioned that disposal of waste without any treatment for land filling and fresh marine water or air is merely bad environmental management practices that pollute the environment. Qian et al. (2011) mentioned that dumping practices are not sensible and it could create serious issues such as ground water contamination, leakage of toxins, air pollution, and unintentional effect on the flora and the fauna (as cited in Aggarwal 2013). Recycling is defined as 'the reuse of materials from returned 
products without conserving the product identity' (Kapetanopoulou and Tagaras, 2011, as cited Agan, Acar and Borodin, 2013). Internal recycling of new raw material, scrap and water for usable material has directly affected financial performance. Agan, Acar and Borodin (2013) explained internal recycling as practices of collecting and reprocessing of material by using recycled raw materials. Fresner (1998) stressed that recycling as one of cleaner production mechanisms (as cited in Agan, Acar and Borodin, 2013). Therefore, researcher proposes:

- H1: Energy reduction (Fossil fuel consumption) has a significant impact on financial performance in the rubber manufacturing companies in Sri Lanka.

- H2: Waste water treatment has a significant impact on financial performance in rubber manufacturing companies in Sri Lanka.

- H3: Internal recycling of raw material has a significant impact on financial performance of rubber manufacturing companies in Sri Lanka.

\section{Control variable}

This variable needs to be held constant during the process to test the relative impact of independent variables. Based on the resource dependence theory (Pfeffer and Salancik 1978), larger firms have more access to capital and more resources to add competency, skills and knowledge to its human capital. Moreover, this factor may contribute to the better performance of the company due to its size advantage. In addition, based on the political cost theory, larger firms also face greater public scrutiny. Due to this, they disclose more information in order to reduce agency costs and avoid being targeted by the regulator for regulatory non- compliance (Watson, Shrives and Marston, 2002). Thus, large companies practice good governance not only for performance but also for other motives. Based on previous environmental management practises on firm performance link research, many of the studies have taken firm size as a control variable. Sahaym, Steensma and Barden (2010) stressed that firms' average size can represent the visibility of their industry. Most of the researchers used company average assets as a control variable to capture the effect of firms' 
average size on firm performance.

\section{Methodology}

This section introduces the methodological slant for the empirical analysis (which tests to use the hypotheses of the research work and the quantum of the data. According to Dewasiri et al. (2018) this is a quantitative study with econometric approach.

Data Collection Approach: Present study which placed financial performance a dependent variable while furnace oil consumption, waste water treatment and recycling of raw material as independent variables. Secondary data was taken from the 30-rubber manufacturing organization within the time period 2012-2016, in Sri Lanka.

Instrument and Measures: Quantitative measures of EMPs and financial performance are well matched for the study to measure relationship between environmental and financial performance. Quantitative measures of both EMPs and FP data are derived from secondary sources of data bases. Previous research has measured the environmental management practices of a firm as the firm may manage their wastes in a number of ways. King and Lenox (2002) have generated two measures as waste generation and Onsite Treatment. This study uses the onsite treatment as one of the independent variables. King and Lenox (2002, p.247) defined onsite treatment as "the degree to which waste is treated onsite as opposed to being released into the environment or transform for third party processing". It is considered in three aspects waste treatment, finance oil consumption, and recycling. The dependent variable of financial performance is measured from ROA. Size of the firm, control variable, is measured through the size of the assets.

Research design: Researcher selects to conduct panel data investigation to examine the driving effect of EMPs on FP. Prior studies employed event study, multivariate statistical techniques, structural equation techniques and other 
statistical techniques based on perception measures of respondents. Environmental measures should be better to consider in long period through different cross sections (time series cross sectional data). Therefore, researcher adapted the panel regression method to evaluate the impact of EMPs on FP from 30 rubber manufacturing companies from 2012 to 2016. Researcher decided to employ two different panel estimation methods: fixed effects (FE) and the random effects (RE) model.

Econometric Specifications: The analysis of the empirical relationship of environmental and financial performance of organizations involves an estimation procedure based on panel data evaluation. Given the nature of the research work and the quantum of the data, the research work study data properties from econometric perspectives, with the help of descriptive statistics and unit root test, this helps us applying a random effect panel data model and a fixed effects panel data model is used. The theory of internalization of externality framework is adopted for this study. The model is derived in the traditional manner from the production function; the performance of a company is expressed as a function of environmental management practices such as furnace oil consumption, waste water treatment and waste recycle. Consequently, the Random effect model for specifying financial performance (ROA) is expressed as follows:

$y_{i t}=\beta_{0}+\beta x_{i t} \ldots \ldots \ldots \ldots \ldots \ldots \ldots+\mu_{j}+\varepsilon_{i t}$

$y_{i t}=\beta_{0}+\beta 1$ Size $_{i t}+\beta_{2}$ Furnace oil $+\beta_{3}$ Waste treatment $+\beta_{4 \text { recycle }}+\mu_{j}+\varepsilon_{i t}$

The equation of the model are grouped into two, equation one and equation two, equation one of the models signify that the data is non-stationary meaning it cannot be co-integrated, to convert the data to stationary, equation two was formed with log on each variable which show that the model is converted to first deference and the data has now become stationary.

$\Delta y_{i t}=\beta_{0}+\beta_{1} \Delta$ size $_{i t}+\beta_{2} \Delta$ furnace-oil $+\beta_{3} \Delta$ waste-treatment $+\beta_{4} \Delta$ recycling

$$
+\mu_{j}+\varepsilon_{i t}
$$

\section{* $\Delta$-First difference}


Where $\mathrm{i}$ denote the firm $(\mathrm{i}=1 \ldots \ldots . \mathrm{n}$ units under observation $) ; \mathrm{j}$ shows the industry: and $t(t=1 \ldots \ldots \ldots \ldots . . . t$ time period of data collected $)$ is the time period. $\mu$ is the industry related fixed effects; $\varepsilon$ is the standard error term. Where $y_{i t}$ denotes the observation of the dependent variable (financial performance is return on sales -ROA) of a firm $\mathrm{I}$ in a period of $\mathrm{t}$, ROS reflect market valuation by consumers and trading bodies. $X_{i t}$ represents the set of time-variant independent variables (repressors), and $\boldsymbol{\mu}_{j}$ is the time -invariant explanatory variables. Then the explanatory variable, size represents the firm size, and as the proxies for environmental management practices, researcher takes furnace oil consumption, waste treatment and recycling, respectively. $\Delta y$ it is the first difference of financial performance (ROA); $\Delta$ (furnace-oil) is the first difference of furnace oil consumption; $\Delta$ (waste treatment) is the first difference of waste water treatment and $\Delta$ recycle is logarithm of recycle of material. Two reasons do not ignore panel structure of data, first due to the pooled model yields estimates by consistent estimates of regression. In analysis, two models random and fixed effects were used, where fixed effects model have the same issue of correlated time-invariant effects in repressors, but it does not appear in random effect model. For the specification of random effects panel data model is as fallows,

$$
\varepsilon_{i t}=\xi i+\eta_{i t}
$$

Where it is composed of the disturbance $\xi \mathrm{i}$ reflecting left-out variables that are remaining broadly over each firm over the time and idiosyncratic error (considered as time-persistence). The main assumption in fixed effects model is individual effect $\xi i$ is correlated with time-variant independent variables Xit. In here $\xi \mathrm{i}$ is a constant or dummy variable for each unit in analysis. The estimation method for random effects regression individual effect. In this model $\xi \mathrm{i}$ is assumed to be time-variant independent variables. 


\section{Results}

\section{The Correlation Matrix}

In the econometric analysis, researcher built up a panel data based on 30 rubber manufacturing companies in Sri Lanka from 2012 to 2016.

Table 2: Descriptive statistics of variables

\begin{tabular}{ccccccccc}
\hline & Mean & Median & $\begin{array}{c}\text { Standard } \\
\text { deviation }\end{array}$ & ROS & FOIL & WASTE & RECY & SIZE \\
\hline ROA & 31.21273 & 31.50000 & 9.116657 & 1.0000 & & & \\
FOIL & 2636.647 & 2800.000 & 1211.456 & $0.466247^{*}$ & 1.0000 & & \\
WASTE & 274.9600 & 120.0000 & 391.5977 & -0.018896 & $-0.261320^{*}$ & 1.0000 & & \\
RECY & 8.740000 & 4.500000 & 10.67986 & 0.049943 & 0.018896 & 0.012535 & 1.0000 & \\
SIZE & 6.143933 & 5.000000 & 4.876484 & $0.150624^{*}$ & 0.012602 & $-0.116083^{*}$ & $0.193792^{*}$ & 1.0000 \\
\hline
\end{tabular}

Source: Author's own elaboration

Table 2 shows the mean, standard deviation and correlation coefficients between the dependent, independent, and control variables along with correlation matrix. Table 1 depicts the correlation between FOIL and ROA is positive, providing evidence to justify $\mathrm{H} 1$. The correlation between WASTE and ROA is negative and the correlation between RECY and ROA is positive, providing evidence to support to $\mathrm{H} 2$ and $\mathrm{H} 3$ respectively.

\section{Regression Result}

\section{Stationary Test (Unit Root Analysis)}

In order to avoid spurious regressions, researcher conducted unit root test for panel data to assess stability before estimating panel regression. There are different estimation methods for unit root test in panel data. In this study two types are preferred, that is unit root test for the same root and different roots. Levin, Lin, and Chu (2002) explained that the Levin-Lin-Chu test (LLC test) can be applied for measuring the same root, further Im-Pesaran-Shin test (IPS test) when different roots are considered. By performing unit root taking all the data into a common platform to precede the analysis. Here the researcher intended to 
check whether all the variables are in the same order of interpretation. As per literature, Levin, Lin and Chu (2002) stressed that (H0- Panel data has unit root (assuming common unit root process; Ha- Panel data has not unit root). Breitung (2001) also stressed that, H0- Panel data has unit root (assuming common unit root process); Ha -Panel data has not unit root. Different approach was suggested by Hadri and Larsson (2005).H0- Panel data has not unit root (assuming individual unit root process) (Stationary); Ha- Panel data has unit root (Non-stationary).

Table 3: Results of unit root tests for panel data

\begin{tabular}{|c|c|c|c|c|c|}
\hline Variable & $\begin{array}{l}\text { LLC test } \\
\text { probability } \\
\text { (level) }\end{array}$ & $\begin{array}{l}\text { LLC test } \\
\text { probability } \\
\text { (Lag 1) }\end{array}$ & $\begin{array}{l}\text { IPS test } \\
\text { probability } \\
\text { (level) }\end{array}$ & $\begin{array}{l}\text { IPS test } \\
\text { probability } \\
\text { (Lag 1) }\end{array}$ & $\begin{array}{l}\text { Hadri test } \\
\text { probability } \\
\text { (Lag 1) }\end{array}$ \\
\hline ROS & $0.0000 * * *$ & $0.0000 * * *$ & $0.0115^{* *}$ & $0.0000 * * *$ & $0.0000 * * *$ \\
\hline FOIL & $0.0000 * * *$ & $0.0003 * * *$ & $0.0579 *$ & $0.0000 * * *$ & $0.0000 * * *$ \\
\hline WASTE & 0.8745 & $0.0000 * * *$ & 0.4761 & $0.0000 * * *$ & $0.0000 * * *$ \\
\hline RCEY & 0.0553 & $0.0007 * * *$ & 0.1606 & $0.0001 * * *$ & $0.0000 * * *$ \\
\hline SIZE & 0.8675 & $0.0000 * * *$ & 0.7834 & $0.0000 * * *$ & $0.0000 * * *$ \\
\hline
\end{tabular}

Source: Author's own elaboration

*** indicates a significant level of $1 \%$, ** indicates a significant level of $5 \%$, *indicates a significant level of $10 \%$

The LLC and IPS test revealed that all of the variables were statistically significant (see Table 3) at the 1percent level (Lag 1). Data were not stationary at level but when it as converted into first difference then they became stationary and it means that data has not unit root in the first difference. Therefore, researcher selected these five variables to perform panel estimation. Definitions and descriptive statistics of five variables are presented in Table 4 respectively. Regression results are presented in Table 6. Researcher shows the result of static panel data estimates for model in Table 5. This section records the results that originated when empirically estimating the relationship between environmental management practices and financial performance based on statistical techniques and explained in section 2 \{random effect (RE) and fixed effect (FE). Hypothesis derived in section 1 of the paper were tested based on two regressions methods 
ex. Table 6 presents the static panel data analysis for of regression model. For each three independent variables and control variable with depended variable, researcher analyses the fixed and random effect model. After the estimation of LSDV and Random effect model, the researcher had to decide which model was appropriate. With the purpose of having robust results, the researcher used Housman Test which checks the suitable model for interpretation.

\section{Empirical result and model specification}

\section{Table 4: variable definition and measurement}

\begin{tabular}{ll}
\hline Key variables & Measurement and definitions \\
\hline ROA & Return on Sales (Firm profit/total sales) \\
FOIL & Furnace oil consumption (liters) per day \\
WASTE & Waste water treated (cubic meters) per day \\
RCYCL & Recycle raw material (as a \% from total output) per \\
& day \\
SIXE & Average firm total assets (rupees million '00') \\
\hline
\end{tabular}

The Hausman test is used to select the appropriate regression model for the analysis. According to the Table 5, the Hausman test revealed that the p value is less than 0.05 , so the null hypothesis of the appropriateness of the cross-section random effect model can be rejected.

Table 5: Hausman Test Result: independent variables and ROA

\begin{tabular}{|c|c|c|c|c|}
\hline \multicolumn{2}{|c|}{ Test Summary } & Chi-Sq. Statistic & Chi-Sq. d.f. & Prob. \\
\hline \multicolumn{2}{|c|}{ Cross-section random } & 12.767587 & 1 & 0.0447 \\
\hline \multicolumn{5}{|c|}{ Cross-section random effects test comparisons: } \\
\hline Variable & Fixed & Random & Var (Diff.) & Prob. \\
\hline DIV1 & 0.071064 & 0.379937 & 0.018500 & 0.0232 \\
\hline DIV2 & -0.148812 & -0.155242 & 0.004010 & 0.9191 \\
\hline
\end{tabular}

*Significant at 5\% level of significance

The model related to fixed effect and random effect, fixed effect is the best specification, since the Wu-Hausman test is significant. Hence, the researcher 
decided to proceed with the Fixed Effect Model for the analysis. Moreover, a CUSUM test was conducted to decide on the stability of the model. The findings revealed that the financial performance (ROA) is a stable variable, since the blue line is located between two red lines in the same test. Table 6 depicts the summary results of the fixed effect panel least squares test and the random effect model. Since the significant value of the F-statistic is less than 0.1 at the 10 percent level of significance, the regression model is significant in explaining the financial performance. The adjusted R-squared value implies that 69 percent of the financial performance variation can be explained through the model. The Durbin-Watson (DW) statistic is not a suitable explanation for non-correlation of errors in panel data. Hence, it is recommended to proceed with the serial correlation LM test, since the DW value is much higher than 2 which reflect a negative serial autocorrelation (see Table 6).

Table 6: The impact of environmental management practices (determinant of financial performance) on financial performance using static panel data analysis

\begin{tabular}{|c|c|c|}
\hline $\begin{array}{l}\text { Dependent (financial } \\
\text { performance-ROS) }\end{array}$ & Fixed & Random \\
\hline Constant & $-13.46877(48.04649)$ & $-13.58707(43.25268)$ \\
\hline $\begin{array}{l}\text { D (Furnace oil } \\
\text { consumption) }\end{array}$ & $162.3028 * * *(48.55810)$ & $106.2565 * *(35.98340)$ \\
\hline $\mathrm{D}$ (waste treatment) & $0.133710(0.478173)$ & $0.245399(0.343990)$ \\
\hline $\mathrm{D}$ (recycle) & $0.223063 * *(0.082518)$ & $0.106706(0.076016)$ \\
\hline $\mathrm{D}($ Size $)$ & $-1.03 \mathrm{E}-06(0.000410)$ & $0.004549(0.006373)$ \\
\hline Hausman & & $22.760072 * *$ \\
\hline R-squared & 0.688178 & 0.102158 \\
\hline F-statistic & 0.498078 & 1.390668 \\
\hline Breusch-Pagan test & 0.0957 & \\
\hline Prob(F-statistic) & 0.098983 & 0.200948 \\
\hline Durbin-Watson stat & 3.477638 & 3.303583 \\
\hline $\begin{array}{l}\text { Serial correlation } \\
\text { (Breusch -Godfry serial } \\
\text { correlation) }\end{array}$ & 1.310 & \\
\hline Number of observations & 120 & 120 \\
\hline
\end{tabular}

Note: (1) Figures in parentheses are slandered errors robust to heteroscedasticity. (ii) Hausman is the Hausman test for fixed effects over random effects. 
(iii) Serial correlation is the test for first order serial correlation in fixed effects models presented by Baltagi (1995). $+\mathrm{p}<0.1,{ }^{*} \mathrm{p}<0.05, * * \mathrm{p}<0.01, * * * \mathrm{p}<0.001$.

D-First difference values

The next step of the data analysis involves the relevant diagnostics tests to check on the regression assumptions. If there are any violations, the researcher could proceed with corrective actions to produce a robust model. The correlations were estimated among the independent variables to check on multicollinearity. The correlation between the variables, and there is no multicollinearity between the variables. This confirms the high discriminant validity of the current study. A Breusch-Godfry serial correlation test was performed to test whether there is a serial autocorrelation (H0: There is no serial correlation in the residual, H1: There is serial correlation in the residual). Since the $\mathrm{p}$ value is greater than the 0.05 , the researcher could not reject null hypothesis and the results revealed that there is no serial correlation among the residuals which is desirable. Since the researcher considered the lagged variables, theoretically there is no room for a serial correlation. One of the major issues arising in panel data is the problem of heteroskedasticity. The results of the Breusch-Pagan test revealed that the p value (0.0957) is greater than 0.05. Hence the researcher could not reject the null hypothesis, implying that the residuals are homoscedastic (same scatter), which is desirable.

The Ramsey RESET Test for Model Specification revealed that the $\mathrm{p}$ value of F-statistics is higher than 0.05 , so the researcher could not reject the null hypothesis that the model has no omitted variables. This result emphasizes that there is no significant evidence for model mis-specification. The Fixed Effect Model summary stated in Table 6 implied that lagged furnace oil consumption and lagged recycling are proxy for environmental management practices and implies a significant determinant of financial performance. According to the Table 6, the coefficient value of the Lagged Furnace oil consumption (162.3028) shows the highest positive impact on dividend yield while waste water treatment $(0.133710)$ and recycle of raw material (0.223063) also showing positive relationships with the financial performance (ROA). 


\section{Impact of Furnace Oil Consumption and Recycle of Waste Water on ROA}

An important question to be answered in this section is to identify whether the significant EMPs may have an impact on ROA. Here, the dependent variable is taken as the lagged ROA whereas the independent is taken as the lagged furnace oil and lagged recycle. Since the independent variables are time and cross sectional variant binary variable. It is suggested to proceed with a sample panel least square (PLS) regression model. The probability to estimate lagged furnace oil and lagged recycle are estimated using the fixed effects specification on panel data. Since the independent variables X1 (lagged waste water), and X2 (lagged recycle) are in dichotomous scale, it can have only two possible outcomes which the researcher denotes as 1 and 0 . Moreover, whether to proceed with fixed effect or random effect model is to be determined by performing the Hausman test. According to the Table 5, the Hausman test revealed that $\mathrm{p}$ value is less than 0.05 , so the null hypothesis of the appropriateness of the cross-section random effect model could be rejected and proposed to proceed with the fixed effect model.

Table 7: Impact of furnace oil consumption and recycle of waste water on ROA: Fixed effect test results

\begin{tabular}{llll}
\hline Variable & Coefficient & Std. Error & Probability \\
\hline C & -27.48022 & 44.50137 & 0.5385 \\
DIV1 (furnace oil) & 0.071064 & 0.488349 & 0.8846 \\
DIV2 (recycle raw material) & -0.148812 & 0.073346 & $0.0991^{+}$ \\
R-squared & 0.325010 & Prob(F-statistic) & 0.091585 \\
Adjusted R- squared & & Durbin-Watson & 2.023045 \\
& 0.066003 & stat & \\
\hline
\end{tabular}

The significant value of the F-statistic is less than 10 per cent level of significant (see Table 7), and the regression model is significant in explaining the lagged ROA. The adjusted R-squared value implies that 6.6 percent of the lagged ROA variation could be explained through the model. The Durbin-Watson (DW) statistic is closer to 2, it implies that errors are uncorrelated. The p-value of lagged furnace oil (IV1) reveals that, it is not significant to explaining the lagged ROA movements. Moreover, lagged recycle is significant in explain the lagged 
ROA movements at significant level of 5 percent. The coefficient value reveals that there is a negative influence of lagged recycle of waste water on the lagged ROA and it is significant to explain at 5 percent level of significant (Table 8).

Table 8: Multiple Regression outcomes with ROA

\begin{tabular}{ll}
\hline $\begin{array}{l}\text { Accepted } \\
\text { Hypothesis }\end{array}$ & Outcome \\
\hline $\mathrm{H} 1_{0}$ & $\begin{array}{l}\text { There is no significant relationship between furnace oil consumption and } \\
\text { ROA }\end{array}$ \\
$\mathrm{H} 3_{\mathrm{a}}$ & $\begin{array}{l}\text { There is a negative significant relationship between recycle of raw } \\
\text { materials and ROA }\end{array}$ \\
\hline
\end{tabular}

\section{Discussion}

In the fixed effect specification, the coefficient on lagged furnace oil consumption is not significant (at the 5\% level) and has a positive coefficient (positive effect on ROA), the coefficient value of the Lagged Furnace oil consumption (162.3028) shows the highest positive impact on ROA, but there is no significant impact towards ROA while waste recycle $(-0.148812)$ has a negative impact on financial performance (ROA) and the effects are economically relevant. Although, due to the short time-horizon of the analysis it cannot fully rule out some longer-term positive effects that are not accounted for and hence the negativity is somewhat less severe than the one revealed here. Waste water treatment and firm size have no significant effect on ROA. For the random effects' specification, the furnace oil coefficient is significant; the Hausman test is significant at 5 percent, suggesting that the random effects estimates may be inconsistent.

Table 9: Summery of the result

\begin{tabular}{ll}
\hline Research aspect & Findings \\
\hline $\begin{array}{l}\text { Hypothesis H1 } \\
\text { but has a positive }\end{array}$ & $\begin{array}{l}\text { Confirmed: There is no significant effect on financial performance, } \\
\text { Relationship with ROA }\end{array}$ \\
$\begin{array}{ll}\text { Hypothesis H2 } \\
\text { ROA }\end{array}$ & $\begin{array}{l}\text { Confirmed no significant relationship but positive relationship with } \\
\text { Hypothesis H3 }\end{array}$ \\
\hline
\end{tabular}


financial performance

Firm size effects No significant impact on financial performance

Source: Author's own elaboration

The salient results of the empirical analysis is summarized in Table 9to endure analysis of the study, There are three hypotheses described; H1, H2 and $\mathrm{H} 3$ particular by with regard to their meaning. Attached managerial implications of the results are developed which bridge the meaningful conclusion.

\section{Conclusion}

This study concentrates on the relationship between environmental management practices and financial performance using a panel database of Sri- Lankan rubber manufacturing firms. The ultimate objective of this study was to find whether environmental management practices have a positive statistically significant relationship with financial performance (ROA). There are a few limitations have to be surmounted in the research period such as environmental management practices since it is a novel concept and it lacks research in the Sri Lankan context. An existing feature of present empirical studies on the relationship between environmental management practices and financial performance is the very limited evidence particularly in the context of panel data analysis. In this study, researcher has assessed static panel data estimates of relationship between EMPs and financial performance by considering 30 rubber companies in Sri Lanka between 2012 and 2016. While static panel data estimates suggested absence of significant impact of lagged waste water treatment and lagged furnace oil consumption on financial performance, whereas, lagged recycle of raw material revealed significant evidence revealing that these practices affect financial performance. Further result revealed that firm size has not significant effect of financial performance. The preponderance of research evidence is that furnace oil consumption has not a strongly impacted on financial performance. Furnace oil burning is directly proportional to energy consumption of a firm that has a significant impact on environment due to greenhouse gas emission. Reductions of finance oil consumption have reduced significant impact of environmental challenges and improved financial performance. Further, recycle 
of raw material also has the significant evidence on financial performance. Moreover, recycle has eliminated land filling and has a significant impact on financial performance. Waste water treatment is a cost for the company; it has a significant effect on greenhouse gas. The above model has not suggested that a significant relationship exists between waste water treatment and financial performance. The clear weight of our evidence is that financial performance was impacted by environmental management practices in terms of recycling of waste material, but not through waste water treatment and furnace oil consumption. Such findings should be considered by managers of the Rubber Industry in particular and by other similar industries when developing environment management practices in the respective industries. However, the findings of the current study can be tested in other industries.

\section{Acknowledgments}

I would like to thank senior professor, K. D Gunawardana for his contribution, suggestions and valuable comments.

\section{References}

Agan, Y., Acar, M. F. and Borodin, A. (2013). Drivers of environmental processes and their impact on performance: a study of Turkish SMEs. Journal of Cleaner Production, 5(1), 23-33.

Aggarwal, P. (2013). Relationship between environmental responsibility and financial performance of firm: a literature review. IOSR Journal of Business and Management, 13(1), 13-22.

Amores, S. J., Martín D. C. G., Navas L. J. E. and Delgado V. M. (2012). Environmental Innovation and Firm Performance. A Natural Resource-Based View.

Bhagat, S., \& Bolton, B. (2008). Corporate governance and firm performance. Journal of corporate finance, 14(3), 257-273.

Breitung, J. (2001). The local power of some unit root tests for panel data. In

Nonstationary panels, panel cointegration, and dynamic panels, 161-177; Emerald Group Publishing Limited. 
Burritt, R.L. (2004). Environmental management accounting: roadblocks on the way to the green and pleasant land. Business Strategy and the Environment, 13(1), 13-32.

Central Bank of Sri Lanka, (2014). Central Bank Report, Available from http://www.cbsl.gov.lk/pics_n_docs/10_pub/_docs/efr/annual_report/AR2014/E nglish/content.htm.

Colby, M. E. (1991). Environmental management in development: the evolution of paradigms. Ecological Economics, 3(3), 193-213.

Davidsson, P., Hunter, E., \& Klofsten, M. (2006). Institutional Forces The Invisible Hand that Shapes Venture Ideas?. International Small Business Journal, 24(2), 115-131.

Delmas, M., (2003). In search of ISO: An institutional perspective on the adoption of international management standards.

Dewasiri, N. J., Weerakoon, Y. K. B., \& Azeez, A. A. (2018). Mixed methods in finance research: The rationale and research designs. International Journal of Qualitative Methods, 17, 1-13.

DiMaggio, P., \& Powell, W. W. (1983). The iron cage revisited: Collective rationality and institutional isomorphism in organizational fields. American sociological review,48(2), 147-160.

DiMaggio, P. J., \& Powell, W. W. eds. (1991). The new institutionalism in organizational analysis (Vol. 17). Chicago, IL: University of Chicago Press.

Edirisinghe, J.C. (2013). Community Pressure and Environmental Compliance: Case of Rubber Processing in Sri Lanka. Journal of Environmental Professionals Sri Lanka, 1(1), 14-23.

Gunathilaka, L. F. D. Z., Gunawardana, K.D., \& Pushpakumari, M.D. (2015). An impact of environmental practices on financial performance. A literature review. $12^{\text {th }}$ International Conference on Business Management (ICBM). 
Gunathilaka, L. F. D. Z., \& Gunawardana, K. D. (2015). Carbon Footprint Calculation from Cradle to Grave: A Case Study of Rubber Manufacturing Process in Sri Lanka, International Journal of Business and Social Science, 6(10), 82-94.

Gunathilaka, L.F.D.Z. and Gunawardana, K. D., (2018). An Analysis of Environmental Management Practices on Financial Performance of Rubber Industry in Sri Lanka. 15th International Conference on Business Management (ICBM 2018).

González-Benito, J, \& González-Benito, Ó. (2005). Environmental proactivity and business performance: an empirical analysis. Omega, 33(1), 1-15.

Hadri, K., \& Larsson, R. (2005). Testing for stationarity in heterogeneous panel data where the time dimension is finite. The Econometrics Journal, 8(1), 55-69.

Hayes, R. H., and Wheelwright, S.C. (1984). Restoring our competitive edge: competing through manufacturing. (ST4071).

Hoffman, A.J., \& Ventresca, M.J. (2002). Organizations, policy and the natural environment: institutional and strategic perspectives. Stanford University Press.

Houghton, R.A., \& Hackler, J.L. (1999). Emissions of carbon from forestry and land-use change in tropical Asia. Global Change Biology, 5(4), 481-492.

Jennings, P.D., \& Zandbergen, P.A. (1995). Ecologically sustainable organizations: An institutional approach. Academy of Management Review, 20(4), 1015-1052.

King, A., \& Lenox, M. (2002). Exploring the locus of profitable pollution reduction. Management Science, 48(2), 289-299.

Klassen, R.D., \& Whybark, D.C. (1999). The impact of environmental technologies on manufacturing performance. Academy of Management Journal, 42(6), 599-615. 
Lawrence, A.T., \& Morell, D. (1995). Leading-edge environmental management: Motivation, opportunity, resources, and processes. Research in corporate social performance and policy, 1, 99-127.

Levy, D.L., \& Rothenberg, S. (2002). Heterogeneity and change in environmental strategy: technological and political responses to climate change in the global automobile industry. Organizations, policy and the natural environment: institutional and strategic perspectives, 173-193.

Levin, A., Lin, C.F., \& Chu, C.S.J. (2002). Unit root tests in panel data: asymptotic and finite-sample properties. Journal of econometrics, 108(1), $1-24$.

Malhi, Y., Roberts, J.T., Betts, R.A., Killeen, T.J., Li, W., \& Nobre, C.A. (2008). Climate change, deforestation, and the fate of the Amazon. Science, 319(5860), 169-172.

Meyer, J.W., \& Rowan, B., (1977). Institutionalized organizations: Formal structure as myth and ceremony. American Journal of sociology, 340-363.

Mignerat, M., and Rivard, S. (2005). Positioning the Institutional Perspective in Information Technology Research.

Montabon, F., Sroufe, R., \& Narasimhan, R. (2007). An examination of corporate reporting, environmental management practices and firm performance. Journal of operations management, 25(5), 998-1014.

Ostrom, E. (2015). Governing the commons. Cambridge university press.

Ostrom, E. (2009). A general framework for analyzing sustainability of social-ecological systems. Science, 325(5939), 419-422.

Ostrom, E. (2008). The challenge of common-pool resources. Environment: Science and Policy for Sustainable Development, 50(4), 8-21.

Ostrom, E. (2010). A multi-scale approach to coping with climate change and other collective action problems solutions, 1(2), 27-36.

Rabinowitz, D. (2010). The commons, and the anthropology of "earthlings" and their atmosphere. Focaal, 57, 104-108. 
Rondinelli, D.A., and Vastag, G. (1996). International environmental standards and corporate policies: an integrative framework. California Management Review, 39(1), 106-112.

Pfeffer, J., \& Salancik, G.R. (1978). The external control of organizations: A resource dependence approach. NY: Harper and Row Publishers.

Powell, R. (1991). Absolute and relative gains in international relations theory. American Political Science Review, 85(4), 1303-1320.

Sahaym, A., Steensma, H.K., \& Barden, J.Q. (2010). The influence of R\&D investment on the use of corporate venture capital: An industry-level analysis. Journal of Business Venturing, 25(4), 376-388.

Schaltegger, S., \& Wagner, M. (2006). Integrative management of sustainability performance, measurement and reporting. International Journal of Accounting, Auditing and Performance Evaluation, 3(1), 1-19.

Watson, A., Shrives, P., \& Marston, C. (2002). Voluntary disclosure of accounting ratios in the UK. The British Accounting Review, 34(4), 289-313. 